\title{
Mn- and Cd-Contaminated Wild Water Spinach: in vitro Human Gastrointestinal Digestion Studies, Bioavailability Evaluation, and Health Risk Assessment
}

\author{
Billy Teck Huat Guan¹, Ferdaus Mohamat-Yusuff ${ }^{1 *}$, Normala Halimoon¹, \\ Christina Seok Yien Yong ${ }^{2}$ \\ ${ }^{1}$ Department of Environmental Sciences, Faculty of Environmental Studies, Universiti Putra Malaysia, \\ 43400 UPM Serdang, Malaysia \\ ${ }^{2}$ Department of Biology, Faculty of Science, Universiti Putra Malaysia, \\ 43400 UPM Serdang, Malaysia
}

Received: 7 November 2016

Accepted: 12 March 2017

\begin{abstract}
Human health may be at risk when consuming edible but metal-contaminated aquatic plants. This present study was conducted to evaluate the bioavailabilities of manganese (Mn) and cadmium (Cd) in metalscontaminated wild water spinach (WWS), Ipomoea aquatic Forssk. through in vitro human gastrointestinal digestions. Additionally, the health risks from consuming the plant were also assessed. Metals-contaminated hydroponic nutrient solutions were used to grow the plants under greenhouse conditions. The plants were harvested after seven days of metal exposure and their edible shoots (stems and leaves) underwent digestions simulated from the human gastrointestinal tract. A standard reference material (peach leaves, SRM 1547) was used to assess the precision and accuracy of the in vitro digestion studies. Results showed that the metal concentrations in plants increased when the treatment concentration increased; the metals concentrations were higher in the raw (RHS) samples than in the cooked (DHS and CHS) samples. The bioavailabilities of $\mathrm{Mn}$ and $\mathrm{Cd}$ were found to be higher in the intestinal extractions than in the gastric extractions. The health risk index (HRI) showed that the adults averagely aged 44 in Selangor, Malaysia was at risk if they consumed Mn-T1-contaminated cooked (CHS) WWS and Cd-contaminated raw (RHS) and cooked (CHS) WWS at T1 and T2 because their HRI values were more than 1.
\end{abstract}

Keywords: manganese, cadmium, gastrointestinal, bioavailabilities, health risk

*e-mail: ferdius@upm.edu.my 


\section{Introduction}

Malaysia is a country that is blessed with fertile soils that are most suitable for agricultural activities to take place. Agricultural activities undoubtedly contribute high agriculture productivity, but at the same time they also inevitably deteriorate our environment [1]. For example, the intense usage of agrochemicals such as inorganic fertilizer, fungicides, and pesticides in the agriculture has become one of the major contributing sources of heavy metal pollution $[2,3]$. Heavy metals such as zinc (Zn), copper $(\mathrm{Cu})$, mercury $(\mathrm{Hg})$, lead $(\mathrm{Pb})$, etc. have unusual and unique properties which include non-biodegradable, undestroyable, non-thermal-degradable, and accumulative [4].

The association of natural occurring phenomena (e.g. acid rain, precipitation, soil erosion, and surface runoff) with the agriculture activities accelerate the production of heavy metal contaminated agricultural runoff [5]. The runoff will eventually leach out from the soil into nearby surface waters such as ponds and lakes [6]. The low-mixing and slow-moving pond and lake water with high heavy metals accumulation are feasible to be uptaken by the living aquatic plants or macrophytes [7]. Great attention should be given to the edible aquatic plants because many of them are used as food, herbs, and medicine [8]. Previous researchers have found that high amounts of heavy metals were able to accumulate in some of the edible aquatic plants, for example, water chestnut (Eleocharis dulcis (Burm. f.) Trin. ex Henschel) [9], water caltrop (Trapa natans L.) [10], lotus (Nelumbo nucifera Gaertn) [11], watercress (Lepidium sativum L.) [12], and wild rice (Oryza longistaminata A. Chev. \& Roehr.) [13].

Manganese $(\mathrm{Mn})$ is an important source of micronutrient, but it becomes toxic when it exists in excessive amounts [14]. The major roles of $\mathrm{Mn}$ in plants, animals, and humans are described in Table 1. On the other hand, cadmium (Cd) is an absolutely non-essential element and it is proven to be one of the most toxic heavy metals [15]. Bhowmik et al. have studied a number of edible aquatic plants that included prickly water lily (Euryale ferox Salisb.), arrowleaf false pickerelweed (Monochoria hastata (L.) Solms), heart-shaped false pickerelweed (Monochoria vaginalis (Burm. f.) C. Presl ex Kunth), lotus (Nelumbo nucifera Gaertn.), garden puff (Neptunia prostrata (Lam.) Baill.), red water lily (Nymphaea rubra Roxb. ex Andrews) and they found the
$\mathrm{Mn}$ and $\mathrm{Cd}$ content was from 0.016 to $3.386 \mathrm{mg} / \mathrm{L}$ and 0.026 to $0.111 \mathrm{mg} / \mathrm{L}$, respectively [16]. In addition, the edible shoot of the broadleaf cattail, Typha latifolia L. and common reed, Phragmites australis (Cav.) Trin. ex Steud. were contaminated with 6.084 and $3.146 \mu \mathrm{g} / \mathrm{g}$ of Cd respectively [17].

Water spinach or Kangkong as called by the locals is one of the popularly grown and consumed vegetables in Malaysia. Water spinach stir-fried with "Sambal" is an all-time favourite dish; however, boiled water spinach is also enjoyed by the locals. Water spinach also ate in other Asian countries like Vietnam, Thailand, China, Philippines, etc. [18]. Water spinach can also be found in the wild and wild water spinach (WWS) is categorized as a type of edible aquatic plant [19]. Wild water spinach is also classified as a type of indigenous vegetables [20] or wild edible plants (WEPs) [21]. The main reason for WEPs harvesting is because they are easily available, free, abundant, and sustainable [22, 23]. Wild edible plants play a significant role in addressing food security in some countries that are suffering from poverty, food shortage, hunger, and poor health and among the countries include Nepal [24], Bangladesh [25], China [26], Mexico [27], and Sub-Saharan Africa [28]. WWS consists of carbohydrate, protein, energy, and minerals, for example, potassium (K), iron $(\mathrm{Fe})$, sodium $(\mathrm{Na})$, calcium $(\mathrm{Ca})$, and magnesium (Mg) [29]. Thus, it serves as a nutritious food source especially for the rural communities like the indigenous people or Orang Asli in Malaysia [30]. Foraging WWS from ponds and lakes for consumption and medicines is a common practice and the indigenous people would also cultivate the WWS to be sold in the markets to get cash income [31], given that WWS has a high yield of $90.000 \mathrm{~kg} / \mathrm{ha}$ [32].

However, the source to where the WWS is harvested is a concern. Wild water spinach can be found in canals, lakes, ponds, and rivers. Several reports state that WWS was found at pond contaminated with high concentrations of $\mathrm{Mn}$ (from 0.260 to $2.960 \mathrm{mg} / \mathrm{L}$ ) that have exceeded the maximum permissible limit of $0.050 \mathrm{mg} / \mathrm{L}$ set by World Health Organization (WHO, 2011) [33, 34]. Furthermore, [35] found that the lake water was contaminated with $\mathrm{Cd}$ as high as $0.740 \mathrm{mg} / \mathrm{L}$ which was a lot higher than the maximum permissible limit of $0.003 \mathrm{mg} / \mathrm{L}$ recommended by WHO in 2011. Water spinach is capable of absorbing heavy metals just like the other aquatic plants mentioned previously $[36,37,38]$. To be precise, $\mathrm{Mn}$ concentration

Table 1. The essential of Mn to plant, animal, and human.

\begin{tabular}{|c|c|c|}
\hline Target & Functions & Reference \\
\hline Plant & $\begin{array}{c}\text { Photosynthesis (e.g. ATP and chlorophyll synthesis); biosynthesis of aromatic amino acids and } \\
\text { secondary products (i.e. lignin and flavonoids; respiration, hormone activation, and defense } \\
\text { mechanism against free radicals (e.g. peroxides, super oxides or hydroxyl ions). }\end{array}$ & $\begin{array}{c}\text { Millaleo et al. } \\
{[15]}\end{array}$ \\
\hline Animal & $\begin{array}{c}\text { Synthesis of cholesterol, steroids, estrogen, and progesterone; keration formation; free radicals } \\
\text { neutralization. }\end{array}$ & $\begin{array}{c}\text { Yatoo et al. } \\
{[16]}\end{array}$ \\
\hline Human & $\begin{array}{c}\text { Bone growth; cartilage and connective tissues developement; reproductive, neuronal, and } \\
\text { immune function; digestion; defense mechanism against free radicals }\end{array}$ & $\begin{array}{c}\text { Santos et al. } \\
{[17]}\end{array}$ \\
\hline
\end{tabular}


of $370 \mu \mathrm{g} / \mathrm{g}$, dry weight was able to be absorbed from wetland water by the water spinach [39] and the concentration greatly exceeded the permissible limit set by the Food and Agriculture Organization/World Health Organization (FAO/WHO, 1984) [40] which was $2 \mu \mathrm{g} / \mathrm{g}$ [41]. As for $\mathrm{Cd}$, the metal concentrations accumulated in water spinach were $0.44 \mu \mathrm{g} / \mathrm{g}$, dry weigh which was above the permissible value of $0.21 \mu \mathrm{g} / \mathrm{g}$ [42] as stated in $\mathrm{FAO} /$ WHO in 1984; and about 0.93 to $2.95 \mu \mathrm{g} / \mathrm{g}$ fresh weigh of Cd was also found [43]. In addition, the results obtained by [44] showed that water spinach is a hyperaccumulator for $\mathrm{Cd}$.

Since WWS was proven that it is capable to bioconcentrate heavy metals from its growing environment [45], therefore human health might be at risk or threatened if the heavy metal-contaminated WWS was consumed. Upon oral exposure to metal-contaminated WWS, the heavy metals will be transferred and bioaccumulated into the human body. The ingested metal-contaminated vegetable will be broken down by the human digestive system and the soluble form of metals will be released and stored in bones and fat tissues [46]. Although it is true that humans are able to eliminate part of the heavy metals during the intestinal digestion by bile and then excreted them out from the body through faeces [47], however, the gradual accumulation and biomagnification of heavy metals in the body may trigger diseases to occur.

Manganese can cause neurotoxicity when humans are exposed to it in the long term and diseases such as Parkinson's disease, Huntington's disease, and mood disorders may arise [48]. In fact, the recommended dietary allowances (RDA) for manganese are between 2.3 to $11 \mathrm{mg} / \mathrm{d}$ and between 1.8 to $11 \mathrm{mg} / \mathrm{d}$ for men and women, respectively [49]. The potential health effects from chronic exposure of $\mathrm{Cd}$ include bone defects, has been reported in Toyama, Japan where locals suffered from Itai-Itai disease with severe osteoporosis after they consumed Cd-contaminated rice [50, 51]. Moreover, $\mathrm{Cd}$ is able to cause various cancers illness such as urinary bladder, stomach, and pancreatic cancer [52]. The tolerable daily intake (TDI), provisional tolerable weekly intake (PTWI), and maximum recommended intake (MRI) of Cd was $21.4 \mu \mathrm{g} / \mathrm{kg}$ body weight/day [53], $7.0 \mu \mathrm{g} / \mathrm{kg}$ body weight/week [54], and $1.0 \mu \mathrm{g} / \mathrm{kg}$ body weight/day [55], respectively.

It is believed that only about $5 \%$ of the ingested amount of $\mathrm{Mn}$ and $\mathrm{Cd}$ will be accessed and uptake in the human gastrointestinal and the absorption very much depends on the exact dose and nutritional composition $[56,57]$. The major organs for $\mathrm{Mn}$ and $\mathrm{Cd}$ storage are the kidneys [58] and bones [59] respectively. The bioavailability of heavy metals in vegetables can be evaluated via the in vitro digestion model [60]. The in vitro gastrointestinal digestive system or physiologically based extraction test (PBET) was utilized with slightly different treatment conditions (time, $\mathrm{pH}$, temperature, chemicals, and amounts) by researchers in the past on different types of vegetables such as Chinese cabbage [18], broccoli [61, 62], red cabbage [63], spinach [64], etc $[65,66]$. In the past, hazard quotient (HQ) [67], health risk index (HRI) [68], daily intake rate (DIR) [69], and target hazard quotients (THQs) [70] were adopted to conduct health risk assessment. Mathematical calculations were used in these methods by substituting known values, for example, the oral reference dose, daily intake of vegetables, average human body weight, and metal concentrations in plants [71]. The outcomes were in numerical forms and the quantitative data were used to express the risk levels.

Drying, freeze-drying, and cooking are the most common food processing methods [72, 73] and their product outputs are showed in Table 2. It is important to identify the effect of processing methods on the bioavailability of heavy metals in the vegetables. Therefore, the study aims to investigate the $\mathrm{Mn}$ and $\mathrm{Cd}$ content of the hydroponically grown metal-contaminated wild water spinach based on three modes of preparation; dried (DHS), raw (RHS), and cooked (CHS) products. Furthermore, the in vitro bioavailability of the heavy metals was also studied, which was based on the human gastrointestinal tract. The heavy metal intake was then assessed in the selected population who consumed a considerable proportion of their daily intake of processed water spinach products (RHS and CHS) and the outcomes can serve as crucial implications in the health risk and safety of consuming these products targeted toward the studied population.

\section{Materials and Methods}

The apparatus and reagents used in this work are listed in Table 3.

Table 2. Processed vegetable products that are available and sold in the market.

\begin{tabular}{|c|c|}
\hline Processing method & Examples of product \\
\hline Drying & Dried oregano, parsley, rosemary, and chive (McCormick \& Company Inc., Maryland, United \\
States).
\end{tabular}


Table 3. List of the apparatus and reagents used.

\begin{tabular}{|c|c|}
\hline Classification & Materials \\
\hline Apparatus & $\begin{array}{c}\text { Atomic absorption spectroscopy (AAS Model AA-6800 Shimadzu) (Shimadzu Corp., Kyoto, Japan), WiseCircu } \\
\text { water bath (Witeg Labortechnik GmbH, Baden-Württemberg, Germany), shaking water bath WSB-18 } \\
\text { (Daihan Scientific Co, Ltd., Seoul, Korea), LABCONCO freeze dryer (Labconco Corp., Missouri, USA), centrifuge } \\
\text { (Kubota Corp., Tokyo, Japan). }\end{array}$ \\
\hline Reagents & 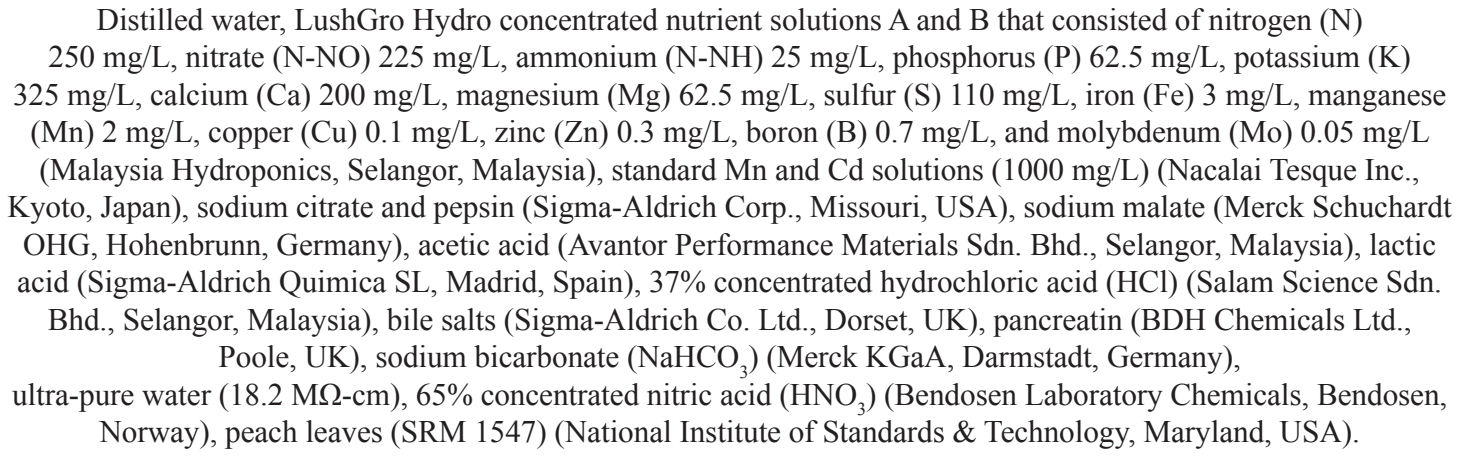 \\
\hline
\end{tabular}

\section{Preparing Metal-Contaminated and Non-Contaminated Water}

Water environment for the growth of the wild water spinach was mimicked through the use of a hydroponic system. Hydroponic nutrient solutions were prepared, one contaminated and another as the control. The contaminated water was exposed to two metal concentration levels, which were low (T1) and high (T2) and the control (C) was without any metal insertion. The insertion was carried out separately for both individual metal experiment (Mn and $\mathrm{Cd}$ ). The concentration levels used in the experiment were the proportion of the metal contamination that happened in the surface water as described in the previously published paper [45]. The treatments were made out of $\mathrm{Mn}-\mathrm{C}, \mathrm{Mn}-$ T1, Mn-T2, Cd-C, Cd-T1, and Cd-T2 and the definition of each treatment are explained in the subsequent paragraph.

For example, the abbreviation Mn-T1 was deduced with the former $(\mathrm{Mn} / \mathrm{Cd})$ referring to the metal used in the experiment which were manganese $(\mathrm{Mn})$ and cadmium (Cd) while the latter abbreviation (C/T1/T2) stands for the control (C), low treatment (T1), and high treatment (T2). The metal-contaminated waters used in this experiment were categorized into $\mathrm{Mn}-\mathrm{T} 1, \mathrm{Mn}-\mathrm{T} 2, \mathrm{Cd}-\mathrm{T} 1$, and $\mathrm{Cd}-$ $\mathrm{T} 2$, while the non-contaminated waters used as $\mathrm{Mn}-\mathrm{C}$ and Cd-C. Metal addition was carried out on Mn-T1 (10 times Mn-C), Mn-T2 (50 times Mn-C), Cd-T1 (100 times Cd$\mathrm{C}$ ), and $\mathrm{Cd}-\mathrm{T} 2$ (500 times $\mathrm{Cd}-\mathrm{C}$ ) and the concentrations in Mn-T1, Mn-T2, Cd-T1, and Cd-T2 were adjusted to approximately $0.3,1.5,0.1$, and $0.5 \mathrm{mg} / \mathrm{L}$, respectively. The Mn-C and Cd-C solutions were mixtures of distilled water and concentrated nutrient solutions $\mathrm{A}$ and $\mathrm{B}$ only.

\section{Growing Water Spinach}

Wild water spinach (WWS) were grown hydroponically under artificial daylight in a greenhouse with temperatures ranging 30.08 to $31.52^{\circ} \mathrm{C}$ and humidity at 53 to $56 \%$. The newly cultivated mature WWS were transplanted into individual pots of the hydroponic containers containing metal-contaminated and non-contaminated water. Cultivated wild water spinach was harvested after seven days of exposures to the metal environment. Edible shoots (stems and leaves) were washed, rinsed, and pre-treated into three products which were dried (DHS), raw (RHS), and cooked (CHS) products. For DHS, the shoots were dried in oven at $70^{\circ} \mathrm{C}$ for 48 hours, which was done by applying the method as recommended by Hussain et al. [74] with slight modifications; for RHS, the shoots were frozen at $-80^{\circ} \mathrm{C}$ and then freeze dried at $-50^{\circ} \mathrm{C}$ for 48 hours according to the freeze-drying method suggested by [75] but with slight modifications; for $\mathrm{CHS}$, the shoots were cooked in boiling water at $100^{\circ} \mathrm{C}$ for $30 \mathrm{~s}$, then were frozen at $-80^{\circ} \mathrm{C}$, and finally freeze dried at $-50^{\circ} \mathrm{C}$ for 48 hours. Cooking then freeze-drying of the sample were carried out by following the method by Nowak [76] with slight modifications.

\section{Digestion of the Water Spinach Products}

The digestion of plant samples was divided into four phases. The first phase involved the use of nitric acid to extract the heavy metals (available fraction) from the samples; the second and third phase involved extraction using the simulated human gastric and intestinal digestion, respectively; and finally the fourth phase (residual fraction), nitric acid was used again to assess the heavy metals content in the residual fraction of the samples. The digestions from the first phase to the fourth phase on the plant samples were carried out in a sequential order. The conditions for the nitric acid and in vitro gastrointestinal digestions will be described in the following sections.

\section{Nitric Acid Digestion}

The first and fourth phases employed the $\mathrm{HNO}_{3}$ digestion procedures conducted by [77] with slight modifications. Pre-digestion was carried out on one 
gram of ground DHS, RHS, and CHS in about $10 \mathrm{~mL}$ of $\mathrm{HNO}_{3}$ for $24 \mathrm{~h}$. The mixtures were further digested at $40^{\circ} \mathrm{C}$ and then $140^{\circ} \mathrm{C}$ for $1 \mathrm{~h}$ and $3 \mathrm{~h}$, respectively. Digestion was completed when a clear mixture was obtained. After that, the mixtures were cooled down; they were filtered through a $0.45 \mu \mathrm{m}$ syringe microfilter into a $50 \mathrm{~mL}$ Sarstedt tube and diluted with ultra-pure water.

\section{In vitro Gastrointestinal Digestion}

Two of the most important digestions in humans are gastric and intestinal digestion were simulated in the second and third phase of plant digestion. The second and third phase employed the in vitro gastrointestinal digestion procedures proposed by [78] with slight adjustments. Both the phases were performed subsequently. In the second phase, the acidic gastric juices were mimicked. Pepsin was used because it is one of the secretions found in the stomach during digestion. About $30 \mathrm{~mL}$ of the prepared gastric solution ( $1.25 \mathrm{~g}$ of pepsin, $0.50 \mathrm{~g}$ of sodium malate, $0.50 \mathrm{~g}$ of sodium citrate, $420.00 \mu \mathrm{L}$ of lactic acid, and $500.00 \mu \mathrm{L}$ of acetic acid) was added to approximately one gram of ground DHS, RHS, and CHS. Concentrated hydrochloric acid was used to adjust the $\mathrm{pH}$ to 2.50 . The mixtures were placed into a thermostatic bath at $37^{\circ} \mathrm{C}$ and shaken at $100 \mathrm{rpm}$ for $1 \mathrm{~h}$. About $5 \mathrm{~mL}$ of aliquots were taken from the mixtures after they were centrifuged at $3000 \mathrm{rpm}$ for $10 \mathrm{~min}$. The aliquots were filtered a through $0.45 \mu \mathrm{m}$ syringe microfilter into a Sarstedt tube and diluted with ultra-pure water. The filters were backflushed with a gastric solution to retain the original solid: solution ratio, i.e. $1: 30 \mathrm{~g} / \mathrm{mL}$ for the next digestion.

As in the third phase, the slightly alkaline intestinal fluid found in the small intestine was imitated by adding

Table 4. Metal contents detected in $\mathrm{SRM}($ mean $\pm \mathrm{SE}, \mathrm{n}=3)$.

\begin{tabular}{|c|c|c|c|c|}
\hline \multirow[b]{2}{*}{ Extraction } & \multicolumn{4}{|c|}{ Metal } \\
\hline & $\begin{array}{c}\mathrm{Mn}^{\mathrm{a}} \\
(\mu \mathrm{g} / \mathrm{g})\end{array}$ & $\% c$ & $\begin{array}{c}\mathrm{Cd}^{\mathrm{a}} \\
(\mu \mathrm{g} / \mathrm{g})\end{array}$ & $\%^{\mathrm{c}}$ \\
\hline $\begin{array}{c}\text { SRM } \\
\text { certified }\end{array}$ & $\begin{array}{c}98.00 \pm \\
3.000\end{array}$ & $\begin{array}{c}100.00 \pm \\
0.000\end{array}$ & $\begin{array}{c}0.026 \pm \\
0.003\end{array}$ & $\begin{array}{c}100.00 \pm \\
0.000\end{array}$ \\
\hline $\begin{array}{c}\text { First } \\
\text { phase } \\
\left(\mathrm{HNO}_{3}\right)\end{array}$ & $\begin{array}{c}93.16 \pm \\
1.490\end{array}$ & $\begin{array}{c}95.06 \pm \\
1.520\end{array}$ & $\begin{array}{c}0.024 \pm \\
0.002\end{array}$ & $\begin{array}{c}93.59 \pm \\
7.798\end{array}$ \\
\hline $\begin{array}{l}\text { Second phase } \\
\text { (gastric) }\end{array}$ & $\begin{array}{c}16.81 \pm \\
0.368\end{array}$ & $\begin{array}{l}17.15 \pm \\
0.375\end{array}$ & $\begin{array}{c}0.002 \pm \\
0.000 \\
\end{array}$ & $\begin{array}{c}8.769 \pm \\
1.059 \\
\end{array}$ \\
\hline $\begin{array}{l}\text { Third phase } \\
\text { (intestinal) }\end{array}$ & $\begin{array}{c}21.27 \pm \\
0.260\end{array}$ & $\begin{array}{c}21.70 \pm \\
0.266\end{array}$ & $\begin{array}{c}0.002 \pm \\
0.000\end{array}$ & $\begin{array}{c}6.795 \pm \\
0.90\end{array}$ \\
\hline $\begin{array}{l}\text { Fourth phase } \\
\text { (residual) }\end{array}$ & $\begin{array}{c}52.77 \pm \\
0.186\end{array}$ & $\begin{array}{c}53.84 \pm \\
0.189\end{array}$ & $\begin{array}{c}0.020 \pm \\
0.000\end{array}$ & $\begin{array}{c}75.77 \pm \\
0.801\end{array}$ \\
\hline $\begin{array}{l}\text { Final phase }^{c} \\
\text { (recovery) }\end{array}$ & $\begin{array}{c}90.84 \pm \\
0.808\end{array}$ & $\begin{array}{c}92.70 \pm \\
0.824\end{array}$ & $\begin{array}{c}0.024 \pm \\
0.001\end{array}$ & $\begin{array}{c}91.33 \pm \\
2.720\end{array}$ \\
\hline
\end{tabular}

\footnotetext{
${ }^{\mathrm{a}}$ : concentration

b: bioavailibity

c: summation of second, third, and fourth phases
}

pancreatin and bile salts to the mixtures during the in vitro digestion. About $52.50 \mathrm{mg}$ of bile salts and $15.00 \mathrm{mg}$ of pancreatin were added to the gastric-digested residues. Saturated $\mathrm{NaHCO}_{3}$ was used to adjust the $\mathrm{pH}$ to 7.00. The mixtures were shaken at $100 \mathrm{rpm}$ for $2 \mathrm{~h}$ in a thermostatic bath maintained at $37^{\circ} \mathrm{C}$. After that, the mixtures were centrifuged at $3000 \mathrm{rpm}$ for $10 \mathrm{~min}$. About $5 \mathrm{~mL}$ of aliquots were removed, filtered, and diluted, which employed the same procedure as mentioned in the previous digestion. The fourth phase of digestion was developed to determine the metal concentrations in the residual (after gastric and intestinal digestions). The metal bioaccessibilities were calculated by applying the formula as follows:

$$
\mathrm{B}=[\mathrm{MD} / \mathrm{MP}] \times 100
$$

Where $\mathrm{B}=$ bioaccessibility (\%), MP = metal present in plant sample before digestion $(\mu \mathrm{g} / \mathrm{g})$, and $\mathrm{MD}=$ metal mobilized from plant sample during digestion $(\mu \mathrm{g} / \mathrm{g})$.

Total recovery (\%) was obtained by adding the bioaccessibility values of gastric, intestinal and residual, while the total loss was the subtraction of total recovery from 100 .

\section{Quality Assurance and Control and Metals Analysis}

Peach leaves (SRM 1547) were used to evaluate the precision and accuracy of the $\mathrm{HNO}_{3}$ (available and residual fraction) and in vitro digestion (gastric and intestinal) methods. The digested SRM and plant samples from all four phases were sent for metals analysis using AAS with an air-acetylene flame. The $\mathrm{Mn}$ and $\mathrm{Cd}$ were quantified by recording the peak height of the signals obtained at 279.5 and $228.8 \mathrm{~nm}$ and lamp currents fixed at 10 and $8 \mathrm{~mA}$ with 0.2 and $0.5 \mathrm{~nm}$ of slit width, respectively. The detected Mn and Cd concentrations by AAS for the SRM are shown in Table 4. The mean Mn recoveries from $\mathrm{HNO}_{3}$ and in vitro digestions were 95.06 and $92.70 \%$, respectively, while for $\mathrm{Cd}$, the means were 93.59 and $91.33 \%$, respectively.

\section{Health Risk Index Determination}

The health risk levels were assessed on the locals for the consumption of raw and cooked vegetables because eating raw [79] and cooked water spinach is commonly practised in Malaysia. The prepared metal-contaminated WWS in different forms (i.e. RHS and CHS) served as the indicator. Health risk index (HRI) was the method adopted during the assessment due to their high validity in addressing health risks. Health risk index was determined by the following equations:

$$
\mathrm{HRI}=\mathrm{DIM} / \mathrm{Rfd}[71]
$$

With DIM as the daily intake of metals, calculated by applying the formula stated below: 


$$
\mathrm{DIM}=[\mathrm{Cm} \times \mathrm{Di}] / \mathrm{Aw}[68]
$$

With $\mathrm{Cm}$ as the heavy metals concentration in plants $(\mathrm{mg} / \mathrm{kg})$; Di as the daily intake of vegetables $(\mathrm{kg} / \mathrm{d})$; Rfd as the oral reference dose, the $\mathrm{Rfd}$ values for $\mathrm{Mn}$ and $\mathrm{Cd}$ are 0.014 [80] and $0.001 \mathrm{mg} / \mathrm{kg} / \mathrm{d}$ [81] respectively; Aw as the mean weight $(\mathrm{kg})$ of the population studied.

Selangor is one of the most populated states in Malaysia, i.e. approximately 6.14 million people according to the Department of Statistics Malaysia (DSM, 2015) [82] and thus the population in Selangor was selected to be studied. In Selangor, the mean body weight of a person was approximately $62.21 \mathrm{~kg}$ in 2003 [83]; in the same year, the daily intake of boiled and raw leafy vegetables for a person in Selangor was approximately $133 \mathrm{~g} /$ day or $0.133 \mathrm{~kg} / \mathrm{d}$ and $34 \mathrm{~g} / \mathrm{d}$ or $0.034 \mathrm{~kg} / \mathrm{d}$, respectively. If the value of the calculated HRI is less than 1, then the exposed population is said to be safe [84].

\section{Analysis of Data}

The obtained data sets were analyzed using analysis of variance (ANOVA), Turkey-Kramer, and regression which are the standard analysis tools found in the Microsoft Office Excel 2007 software. One-way ANOVA was used to evaluate statistical differences among the means of the heavy metal concentrations and bioaccessibilities.

\section{Results and Discussion}

\section{Metals Detected in Plant Samples}

Tables 5 and 6 show the means of the total metal concentrations for DHS, RHS, and CHS at different treatments and phases. It was observed that the metal concentrations varied from DHS-RHS-CHS, C-T1-T2, and first-second-third-fourth phases.

\section{DHS-RHS-CHS}

Concentrations in the DHS ranged from 0.218 to 8.780 and 0.445 to $9.687 \mu \mathrm{g} / \mathrm{g}$ for $\mathrm{Mn}$ and $\mathrm{Cd}$, respectively; the RHS ranged from 0.090 to 3.217 and 0.465 to $10.705 \mu \mathrm{g} / \mathrm{g}$ for Mn and Cd, respectively; while the CHS ranged from 0.207 to 7.325 and 0.653 to $9.438 \mu \mathrm{g} / \mathrm{g}$ for $\mathrm{Mn}$ and $\mathrm{Cd}$, respectively. From the regression statistics (Tables 7 and 8), the total Mn content was higher in the cooked WWS that is DHS (slope value $=3.75$ ) and CHS (slope value $=1.27$ ) than in raw WWS (RHS) with slope value of 1.12 whereas the total $\mathrm{Cd}$ content was higher in raw WWS (slope value $=19.50$ ) than in the cooked WWS with the slope values of 16.97 and 13.88 for DHS and CHS, respectively.

In this work, it has further reinforced the study done by [85] on the effects of cooking methods such as blanching (CHS) and drying (DHS) to the metal concentrations in water spinach. The lowest Mn concentration was found in the raw WWS (RHS) which is in agreement with the findings by [86] reported that the metals concentrations were higher in cooked vegetable when compared with the uncooked one. In this study, the Cd concentration from cooked WWS was lower compared to the raw WWS and cooking did increase the bioaccessibility of $\mathrm{Cd}$ in the steamed French bean, carrot, and leek which was found by [87]. Furthermore, the mean concentrations of other non-essential elements like arsenic (As) and lead $(\mathrm{Pb})$ were higher in cooked vegetables than in raw vegetables [88]. Cooking of WWS may reduce the Cd content as supported by [89] and a significant amount of Cd content was reduced by cooking demonstrated by [90] on a different kind of rice. The lowest $\mathrm{Cd}$ concentration found in CHS was probably due to its leaching into surrounding water during blanching and the blanching could cause cell lysis [91]. The differences in metal concentrations in the DHS, RHS, and CHS may also affect by factors such as the solubility [92] and chelating effect [93].

Table 5. Mn concentrations detected in samples at different treatment concentrations and phases (mean $\pm \mathrm{SE}, \mathrm{n}=3$ ).

\begin{tabular}{|c|c|c|c|}
\hline \multirow{2}{*}{ Sample } & \multicolumn{3}{|c|}{$\operatorname{Mn}(\mu \mathrm{g} / \mathrm{g})$} \\
\hline & $\mathrm{C}$ & $\mathrm{T} 1$ & $\mathrm{~T} 2$ \\
\hline \multicolumn{4}{|c|}{ First phase $\left(\mathrm{HNO}_{3}\right)$} \\
\hline DHS & $\begin{array}{c}1.588 \pm \\
0.093\end{array}$ & $\begin{array}{c}7.413 \pm \\
0.144\end{array}$ & $\begin{array}{c}8.780 \pm \\
0.133\end{array}$ \\
\hline RHS & $\begin{array}{c}0.676 \pm \\
0.057\end{array}$ & $\begin{array}{c}3.217 \pm \\
0.157\end{array}$ & $\begin{array}{c}3.107 \pm \\
0.231\end{array}$ \\
\hline CHS & $\begin{array}{c}0.950 \pm \\
0.043\end{array}$ & $\begin{array}{c}7.325 \pm \\
0.270\end{array}$ & $\begin{array}{c}4.920 \pm \\
0.377\end{array}$ \\
\hline \multicolumn{4}{|c|}{ Second phase (gastric) } \\
\hline DHS & $\begin{array}{c}0.218 \pm \\
0.036\end{array}$ & $\begin{array}{c}2.053 \pm \\
0.023\end{array}$ & $\begin{array}{c}1.507 \pm \\
0.048\end{array}$ \\
\hline RHS & $\begin{array}{c}0.090 \pm \\
0.029\end{array}$ & $\begin{array}{c}0.493 \pm \\
0.197\end{array}$ & $\begin{array}{c}0.853 \pm \\
0.189\end{array}$ \\
\hline CHS & $\begin{array}{c}0.207 \pm \\
0.007\end{array}$ & $\begin{array}{c}1.360 \pm \\
0.173\end{array}$ & $\begin{array}{c}1.147 \pm \\
0.179\end{array}$ \\
\hline \multicolumn{4}{|c|}{ Third phase (intestinal) } \\
\hline DHS & $\begin{array}{c}0.542 \pm \\
0.028\end{array}$ & $\begin{array}{c}1.627 \pm \\
0.131\end{array}$ & $\begin{array}{c}2.373 \pm \\
0.116\end{array}$ \\
\hline RHS & $\begin{array}{c}0.188 \pm \\
0.027\end{array}$ & $\begin{array}{c}0.853 \pm \\
0.173\end{array}$ & $\begin{array}{c}0.493 \pm \\
0.141\end{array}$ \\
\hline CHS & $\begin{array}{c}0.274 \pm \\
0.016\end{array}$ & $\begin{array}{c}1.880 \pm \\
0.101\end{array}$ & $\begin{array}{c}1.373 \pm \\
0.058\end{array}$ \\
\hline \multicolumn{4}{|c|}{ Fourth phase (residual) } \\
\hline DHS & $\begin{array}{c}0.808 \pm \\
0.031\end{array}$ & $\begin{array}{c}3.533 \pm \\
0.045\end{array}$ & $\begin{array}{c}4.764 \pm \\
0.058\end{array}$ \\
\hline RHS & $\begin{array}{c}0.388 \pm \\
0.014\end{array}$ & $\begin{array}{c}1.800 \pm \\
0.231\end{array}$ & $\begin{array}{c}1.705 \pm \\
0.138\end{array}$ \\
\hline CHS & $\begin{array}{c}0.450 \pm \\
0.024\end{array}$ & $\begin{array}{c}3.956 \pm \\
0.022\end{array}$ & $\begin{array}{c}2.302 \pm \\
0.136\end{array}$ \\
\hline
\end{tabular}


Table 6. Cd concentrations detected in samples at different treatment concentrations and phases (mean $\pm \mathrm{SE}, \mathrm{n}=3$ ).

\begin{tabular}{|c|c|c|c|}
\hline \multirow{2}{*}{ Sample } & \multicolumn{3}{|c|}{$\mathrm{Cd}(\mu \mathrm{g} / \mathrm{g})$} \\
\hline & $\mathrm{C}$ & $\mathrm{T} 1$ & $\mathrm{~T} 2$ \\
\hline \multicolumn{4}{|c|}{ First phase $\left(\mathrm{HNO}_{3}\right)$} \\
\hline DHS & $\mathrm{ND}^{* *}$ & $\begin{array}{c}5.309 \pm \\
0.045\end{array}$ & $\begin{array}{c}9.687 \pm \\
0.235\end{array}$ \\
\hline RHS & $\mathrm{ND}^{* *}$ & $\begin{array}{c}4.821 \pm \\
0.168\end{array}$ & $\begin{array}{c}10.705 \pm \\
0.229\end{array}$ \\
\hline CHS & $\mathrm{ND}^{* *}$ & $\begin{array}{c}8.885 \pm \\
0.247\end{array}$ & $\begin{array}{c}9.438 \pm \\
0.343\end{array}$ \\
\hline \multicolumn{4}{|c|}{ Second phase (gastric) } \\
\hline DHS & $\mathrm{ND}^{* *}$ & $\begin{array}{c}0.516 \pm \\
0.115\end{array}$ & $\begin{array}{c}1.469 \pm \\
0.065\end{array}$ \\
\hline RHS & $\mathrm{ND}^{* *}$ & $\begin{array}{c}0.704 \pm \\
0.009\end{array}$ & $\begin{array}{c}0.981 \pm \\
0.079\end{array}$ \\
\hline CHS & $\mathrm{ND}^{* *}$ & $\begin{array}{c}0.981 \pm \\
0.079\end{array}$ & $\begin{array}{c}1.340 \pm \\
0.096\end{array}$ \\
\hline \multicolumn{4}{|c|}{$\begin{array}{l}\text { Third phase } \\
\text { (intestinal) }\end{array}$} \\
\hline DHS & $\mathrm{ND}^{* *}$ & $\begin{array}{c}0.445 \pm \\
0.078\end{array}$ & $\begin{array}{c}1.085 \pm \\
0.094\end{array}$ \\
\hline RHS & $\mathrm{ND}^{* *}$ & $\begin{array}{c}0.465 \pm \\
0.017\end{array}$ & $\begin{array}{c}0.813 \pm \\
0.036\end{array}$ \\
\hline CHS & $\mathrm{ND}^{* *}$ & $\begin{array}{c}0.764 \pm \\
0.096\end{array}$ & $\begin{array}{c}0.653 \pm \\
0.079\end{array}$ \\
\hline \multicolumn{4}{|c|}{ Fourth phase (residual) } \\
\hline DHS & $\mathrm{ND}^{* *}$ & $\begin{array}{c}4.245 \pm \\
0.149\end{array}$ & $\begin{array}{c}6.999 \pm \\
0.115\end{array}$ \\
\hline RHS & $\mathrm{ND}^{* *}$ & $\begin{array}{c}3.547 \pm \\
0.153\end{array}$ & $\begin{array}{c}8.716 \pm \\
0.166\end{array}$ \\
\hline CHS & $\mathrm{ND}^{* *}$ & $\begin{array}{c}7.333 \pm \\
0.064\end{array}$ & $\begin{array}{c}7.269 \pm \\
0.175\end{array}$ \\
\hline
\end{tabular}

**: not detectable

\section{$C-T 1-T 2$}

Concentrations in the $\mathrm{C}$ were within the range of 0.090 to $1.588 \mu \mathrm{g} / \mathrm{g}$ for $\mathrm{Mn}$ and $0.000 \mu \mathrm{g} / \mathrm{g}$ for $\mathrm{Cd}$; the $\mathrm{T} 1$ ranged from 0.493 to $7.413 \mu \mathrm{g} / \mathrm{g}$ for $\mathrm{Mn}$ and 0.445 to $8.885 \mu \mathrm{g} / \mathrm{g}$ for $\mathrm{Cd}$; while the $\mathrm{T} 2$ ranged from 0.493 to $8.780 \mu \mathrm{g} / \mathrm{g}$ for $\mathrm{Mn}$ and 0.653 to $10.705 \mu \mathrm{g} / \mathrm{g}$ for $\mathrm{Cd}$. From the results, it can be defined that the accumulations of both metals in the WWS increased when the treatment concentrations increased from $\mathrm{C}$ to $\mathrm{T} 2$ which were also experienced in other edible aquatic plants, for example, the water chestnut, Trapa natans var. bispinosa Roxb [94] and taro, Colocasia esculenta (L. Schott) [95]. The total metal content accumulated in an aquatic plant like the WWS may vary based on the species of the plant, type of element, biotic and abiotic factors [96]. Besides that, the metal accumulation may depend on the bioavailability of the metal, the retention time of the metal, and the interaction of the metal with other elements and substances in the water phase [97].

\section{First-Second-Third-Fourth Phases}

Concentrations in the first phase ranged from 0.676 to 8.780 and 4.821 to $10.705 \mu \mathrm{g} / \mathrm{g}$ for $\mathrm{Mn}$ and $\mathrm{Cd}$, respectively; the second phase ranged from 0.090 to 2.053 and 0.516 to $1.469 \mu \mathrm{g} / \mathrm{g}$ for $\mathrm{Mn}$ and $\mathrm{Cd}$, respectively; the third phase ranged from 0.188 to 2.373 and 0.445 to $1.085 \mu \mathrm{g} / \mathrm{g}$ for $\mathrm{Mn}$ and $\mathrm{Cd}$, respectively; while the fourphase ranged from 0.388 to 4.764 and 3.547 to $8.716 \mu \mathrm{g} / \mathrm{g}$ for $\mathrm{Mn}$ and $\mathrm{Cd}$, respectively. It was shown that the total metal content was different among the digestion phases $\left(\mathrm{HNO}_{3}\right.$, gastric, intestinal, and residual). For example, the $\mathrm{Mn}$ bioaccessibility in the lettuce (Lactuca sativa L.) leaves decreased in the order of gastric $>$ residual $>$ intestinal [98], while [99] revealed that the solubility of $\mathrm{Cd}$ in the cock's comb (Celosia argentea L.) followed the order gastric $>$ residual $>$ intestinal. The bioaccessibility of metals from the different digestion phases is dependent on several factors such as the digestion and release of the ingested food matrix [100].

Notice that in Fig. 1, all the extracted mean concentrations from DHS, RHS, and CHS by $\mathrm{HNO}_{3}$ digestion exceeded the maximum permissible limits for Cd in leafy vegetables set by the Australian Department of Agriculture and Water Resources, $2015(0.1 \mu \mathrm{g} / \mathrm{g})$ [101], Commission Regulation, 2006 (0.2 $\mu \mathrm{g} / \mathrm{g})$ [102], Hong Kong Food and Environmental Hygiene Department, Centre for Food Safety, $2006(0.1 \mu \mathrm{g} / \mathrm{g})$ [103], and Malaysian Food Regulations, 1985 (1.0 $\mu \mathrm{g} / \mathrm{g})$ [104]. Furthermore, the mean concentrations have also surpassed the Cd limits by Chinese Ministry of Health, 2005 (within 0.05 to $0.2 \mu \mathrm{g} / \mathrm{g}$ ) [105, 106], Food and Agriculture Organization/World Health Organization, 2001 (within 0.02 to $0.2 \mu \mathrm{g} / \mathrm{g}$ ) [107], and World Health Organization/ European Union, $1983(0.01 \mu \mathrm{g} / \mathrm{g})$ [108].

Table 7. Regression statistics on the Mn concentration for DHS, RHS, and CHS.

\begin{tabular}{|c|c|c|c|c|c|}
\hline Product & P-value & Slope & Equation & $\mathrm{R}^{2 \mathrm{a}}$ & $95 \% \mathrm{CI}^{\mathrm{b}}$ \\
\hline DHS & 0.02 & 3.75 & $\mathrm{y}=3.75 \mathrm{x}+3.64$ & 0.59 & {$[0.95,6.55]$} \\
\hline RHS & 0.09 & 1.12 & $\mathrm{y}=1.12 \mathrm{x}+1.65$ & 0.36 & {$[-0.21,2.46]$} \\
\hline CHS & 0.42 & 1.27 & $\mathrm{y}=1.27 \mathrm{x}+3.62$ & 0.09 & {$[-2.27,4.81]$} \\
\hline
\end{tabular}

\footnotetext{
a: coefficient of determination $\quad{ }^{b}$ : confidence interval
} 
Table 8. Regression statistics on the Cd concentration for DHS, RHS, and CHS.

\begin{tabular}{|c|c|c|c|c|c|}
\hline Product & P-value & Slope & Equation & $\mathrm{R}^{2 \mathrm{a}}$ & $95 \% \mathrm{CI}^{\mathrm{b}}$ \\
\hline DHS & 0.00 & 15.40 & $\mathrm{y}=15.40 \mathrm{x}+2.43$ & 0.94 & {$[11.88,18.92]$} \\
\hline RHS & 0.00 & 17.39 & $\mathrm{y}=17.39 \mathrm{x}+2.28$ & 0.98 & {$[15.16,19.63]$} \\
\hline CHS & 0.01 & 13.68 & $\mathrm{y}=13.68 \mathrm{x}+3.83$ & 0.62 & {$[4.08,23.28]$} \\
\hline a: coefficient of determination & b: confidence interval \\
\hline
\end{tabular}

Table 9. Mn bioavailabilities in dried, raw, and cooked samples at $\mathrm{C}, \mathrm{T} 1$, and $\mathrm{T} 2$ treatment (mean $\pm \mathrm{SE}, \mathrm{n}=3$ ).

\begin{tabular}{|c|c|c|c|}
\hline \multirow{2}{*}{ Plant sample } & \multicolumn{3}{|c|}{ Bioavailability of Mn (\%) } \\
\hline & $\mathrm{C}$ & $\mathrm{T} 1$ & $\mathrm{~T} 2$ \\
\hline \multicolumn{4}{|c|}{ Gastric phase } \\
\hline DHS & $\begin{array}{c}13.56 \pm \\
1.548\end{array}$ & $\begin{array}{c}27.71 \pm \\
0.286\end{array}$ & $\begin{array}{c}17.15 \pm \\
0.356\end{array}$ \\
\hline RHS & $\begin{array}{c}12.78 \pm \\
3.459\end{array}$ & $\begin{array}{c}14.91 \pm \\
5.516\end{array}$ & $\begin{array}{c}26.84 \pm \\
4.372\end{array}$ \\
\hline CHS & $\begin{array}{c}21.78 \pm \\
0.433\end{array}$ & $\begin{array}{c}18.44 \pm \\
1.750\end{array}$ & $\begin{array}{c}23.04 \pm \\
1.818\end{array}$ \\
\hline \multicolumn{4}{|c|}{ Intestinal phase } \\
\hline DHS & $\begin{array}{c}34.13 \pm \\
0.280\end{array}$ & $\begin{array}{c}21.89 \pm \\
1.336\end{array}$ & $\begin{array}{c}27.01 \pm \\
0.959\end{array}$ \\
\hline RHS & $\begin{array}{c}27.46 \pm \\
1.821\end{array}$ & $\begin{array}{c}26.18 \pm \\
4.202\end{array}$ & $\begin{array}{c}15.48 \pm \\
3.604\end{array}$ \\
\hline CHS & $\begin{array}{c}28.85 \pm \\
0.797\end{array}$ & $\begin{array}{c}25.63 \pm \\
0.461\end{array}$ & $\begin{array}{c}28.06 \pm \\
0.976\end{array}$ \\
\hline \multicolumn{4}{|c|}{ Residual phase } \\
\hline DHS & $\begin{array}{c}50.99 \pm \\
1.093\end{array}$ & $\begin{array}{c}47.68 \pm \\
0.682\end{array}$ & $\begin{array}{c}54.30 \pm \\
1.437\end{array}$ \\
\hline RHS & $\begin{array}{c}58.21 \pm \\
4.965\end{array}$ & $\begin{array}{c}56.70 \pm \\
9.300\end{array}$ & $\begin{array}{c}55.87 \pm \\
7.522\end{array}$ \\
\hline CHS & $\begin{array}{c}47.38 \pm \\
0.879\end{array}$ & $\begin{array}{c}54.15 \pm \\
1.920\end{array}$ & $\begin{array}{c}46.91 \pm \\
0.856\end{array}$ \\
\hline \multicolumn{4}{|c|}{ Total recovery } \\
\hline DHS & $\begin{array}{c}98.67 \pm \\
0.305\end{array}$ & $\begin{array}{c}97.28 \pm \\
0.534\end{array}$ & $\begin{array}{c}98.46 \pm \\
0.585\end{array}$ \\
\hline RHS & $\begin{array}{c}98.44 \pm \\
0.316\end{array}$ & $\begin{array}{c}97.79 \pm \\
0.463\end{array}$ & $\begin{array}{c}98.18 \pm \\
0.295\end{array}$ \\
\hline CHS & $\begin{array}{c}98.01 \pm \\
0.223\end{array}$ & $\begin{array}{c}98.21 \pm \\
0.484\end{array}$ & $\begin{array}{c}98.00 \pm \\
0.447\end{array}$ \\
\hline \multicolumn{4}{|c|}{ Total loss } \\
\hline DHS & $\begin{array}{l}1.33 \pm \\
0.305\end{array}$ & $\begin{array}{l}2.72 \pm \\
0.534\end{array}$ & $\begin{array}{l}1.54 \pm \\
0.585\end{array}$ \\
\hline RHS & $\begin{array}{l}1.56 \pm \\
0.316\end{array}$ & $\begin{array}{l}2.21 \pm \\
0.463\end{array}$ & $\begin{array}{l}1.82 \pm \\
0.295\end{array}$ \\
\hline CHS & $\begin{array}{l}1.99 \pm \\
0.233\end{array}$ & $\begin{array}{l}1.79 \pm \\
0.484\end{array}$ & $\begin{array}{l}2.00 \pm \\
0.447\end{array}$ \\
\hline
\end{tabular}

Table 10. Cd bioavailabilities in dried, raw, and cooked samples at $\mathrm{C}, \mathrm{T} 1$, and $\mathrm{T} 2$ treatment (mean $\pm \mathrm{SE}, \mathrm{n}=3$ ).

\begin{tabular}{|c|c|c|c|}
\hline \multirow{2}{*}{ Plant sample } & \multicolumn{3}{|c|}{ Bioavailability of Cd (\%) } \\
\hline & $\mathrm{C}$ & $\mathrm{T} 1$ & $\mathrm{~T} 2$ \\
\hline \multicolumn{4}{|c|}{ Gastric phase } \\
\hline DHS & $\mathrm{ND}^{* *}$ & $\begin{array}{l}9.69 \pm \\
2.089\end{array}$ & $\begin{array}{c}15.15 \pm \\
0.311\end{array}$ \\
\hline RHS & ND** & $\begin{array}{c}14.63 \pm \\
0.368\end{array}$ & $\begin{array}{l}9.14 \pm \\
0.535\end{array}$ \\
\hline CHS & $\mathrm{ND}^{* *}$ & $\begin{array}{l}7.10 \pm \\
1.113\end{array}$ & $\begin{array}{c}14.16 \pm \\
0.555\end{array}$ \\
\hline \multicolumn{4}{|c|}{ Intestinal phase } \\
\hline DHS & ND** & $\begin{array}{l}8.36 \pm \\
1.386\end{array}$ & $\begin{array}{c}11.18 \pm \\
0.788\end{array}$ \\
\hline RHS & ND** & $\begin{array}{l}9.65 \pm \\
0.046\end{array}$ & $\begin{array}{l}7.59 \pm \\
0.180\end{array}$ \\
\hline CHS & $\mathrm{ND}^{* *}$ & $\begin{array}{l}8.55 \pm \\
0.844\end{array}$ & $\begin{array}{l}6.88 \pm \\
0.606\end{array}$ \\
\hline \multicolumn{4}{|c|}{ Residual phase } \\
\hline DHS & $\mathrm{ND}^{* *}$ & $\begin{array}{c}80.01 \pm \\
3.434\end{array}$ & $\begin{array}{c}72.29 \pm \\
1.202\end{array}$ \\
\hline RHS & $\mathrm{ND}^{* *}$ & $\begin{array}{c}73.55 \pm \\
0.735\end{array}$ & $\begin{array}{c}81.43 \pm \\
0.560\end{array}$ \\
\hline CHS & $\mathrm{ND}^{* *}$ & $\begin{array}{c}82.63 \pm \\
1.593 \\
\end{array}$ & $\begin{array}{c}77.09 \pm \\
0.988 \\
\end{array}$ \\
\hline \multicolumn{4}{|c|}{ Total recovery } \\
\hline DHS & $\mathrm{ND}^{* *}$ & $\begin{array}{c}98.06 \pm \\
0.413\end{array}$ & $\begin{array}{c}98.63 \pm \\
0.182\end{array}$ \\
\hline RHS & $\mathrm{ND}^{* *}$ & $\begin{array}{c}97.82 \pm \\
0.407\end{array}$ & $\begin{array}{c}98.17 \pm \\
0.574\end{array}$ \\
\hline CHS & $\mathrm{ND}^{* *}$ & $\begin{array}{c}98.28 \pm \\
0.313\end{array}$ & $\begin{array}{c}98.13 \pm \\
0.360\end{array}$ \\
\hline \multicolumn{4}{|c|}{ Total loss } \\
\hline DHS & $\mathrm{ND}^{* *}$ & $\begin{array}{l}1.94 \pm \\
0.413\end{array}$ & $\begin{array}{l}1.37 \pm \\
0.182\end{array}$ \\
\hline RHS & $\mathrm{ND}^{* *}$ & $\begin{array}{l}2.18 \pm \\
0.407\end{array}$ & $\begin{array}{l}1.83 \pm \\
0.574\end{array}$ \\
\hline CHS & $\mathrm{ND}^{* *}$ & $\begin{array}{l}1.72 \pm \\
0.313\end{array}$ & $\begin{array}{l}1.87 \pm \\
0.360\end{array}$ \\
\hline
\end{tabular}

**: not detectable 
Table 11. Regression statistics on the bioavailability of Mn for DHS, RHS, and CHS in the gastric phase.

\begin{tabular}{|c|c|c|c|c|c|}
\hline Element & P-value & Slope & Equation & $\mathrm{R}^{2 \mathrm{a}}$ & $95 \% \mathrm{CI}^{\mathrm{b}}$ \\
\hline DHS & 0.80 & -0.97 & $\mathrm{y}=-0.97 \mathrm{x}+20.06$ & 0.01 & {$[-9.53,7.59]$} \\
\hline RHS & 0.04 & 9.68 & $\mathrm{y}=9.68 \mathrm{x}+12.27$ & 0.48 & {$[0.71,18.64]$} \\
\hline CHS & 0.29 & 1.76 & $\mathrm{y}=1.76 \mathrm{x}+20.01$ & 0.16 & {$[-1.91,5.43]$} \\
\hline a: coefficient of determination & b: confidence interval \\
\hline
\end{tabular}

Table 12. Regression statistics on the bioavailability of Mn for DHS, RHS, and CHS in the intestinal phase.

\begin{tabular}{|c|c|c|c|c|c|}
\hline Element & P-value & Slope & Equation & $\mathrm{R}^{2 \mathrm{a}}$ & $95 \% \mathrm{CI}^{\mathrm{b}}$ \\
\hline DHS & 0.51 & -2.08 & $\mathrm{y}=-2.08 \mathrm{x}+28.95$ & 0.07 & {$[-9.11,4.95]$} \\
\hline RHS & 0.02 & -8.38 & $\mathrm{y}=-8.38 \mathrm{x}+28.15$ & 0.56 & {$[-15.07,-1.70]$} \\
\hline CHS & 0.82 & 0.24 & $\mathrm{y}=0.24 \mathrm{x}+27.37$ & 0.01 & {$[-2.20,2.68]$} \\
\hline \multicolumn{2}{|c|}{ a: coefficient of determination } \\
\hline
\end{tabular}

\section{Bioaccessibilities of Metals}

The calculated bioaccessibility values for gastric, intestinal and residual at different treatment concentrations and type of samples are presented in Tables 9 and 10.

\section{$\mathrm{Mn}$}

The regression statistics (Tables 11 and 12) indicated that the highest in Mn extraction was from RHS after

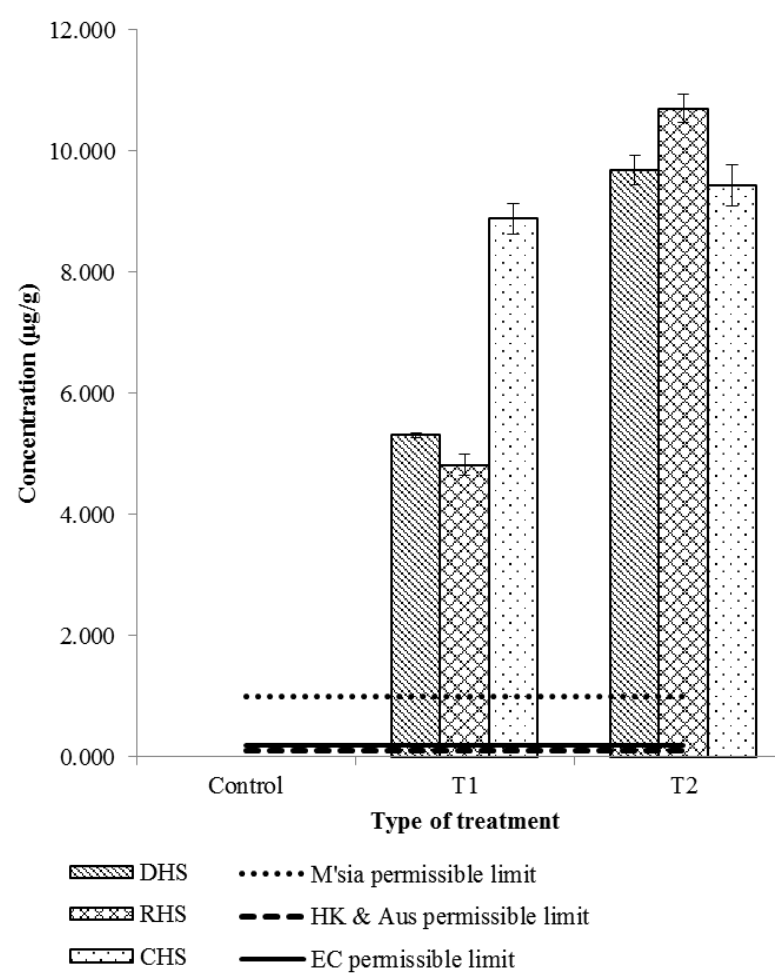

Fig. 1. Comparisons between the mean $\mathrm{Cd}$ concentrations and maximum permissible limits (mean $\pm \mathrm{SE}, \mathrm{n}=3$ ). taken into consideration of the slope value of 9.68 in the gastric phase. However, in the intestinal phase, the highest in $\mathrm{Mn}$ extraction was from CHS with the highest slope value (0.24). In overall, a higher level of Mn was able to be extracted from the plant during gastric than intestinal digestion based on the slope values recorded in Tables 11 and 12. The results here were in line with the results obtained by [109] that the bioavailable percentage of $\mathrm{Mn}$ in the spinach (Spinacia oleracea L.) leaves were from 63.63 to $66.23 \%$ in the gastric phase which was higher than in the intestine phase that ranged from 27.85 to $31.82 \%$. From the one-way ANOVA, it can be summarized that there was a difference in the mean Mn bioaccessibilities observed at different treatment concentrations for DHS (F statistical value $>$ F critical value, $p<0.05$ ). A tukeykramer procedure was done and it showed that there were statistically significant differences between all pairs of comparison except for $\mathrm{C}$ and $\mathrm{T} 2$ in the gastric digestion; while it was found that there were statistically significant differences between all three comparisons in the intestinal digestion.

\section{$C d$}

The regression statistics showed that the highest $\mathrm{Cd}$ extraction was from DHS in the gastric and intestinal phase with slope values of 25.55 and 17.99 respectively. Overall, a higher level of Cd was able to be extracted from the WWS during gastric than intestinal digestion as estimated by the slope values shown in Tables 13 and 14. The phenomenon of higher bioaccessibilities of $\mathrm{Cd}$ in the gastric than intestinal phase occurring in WWS was supported by [65] and [87] who they found that the average bioaccessibilities of $\mathrm{Cd}$ varied within 14 to $71 \%$ and 7 to $25 \%$ and $85 \%$ and $69 \%$ in the gastric and intestinal phase, respectively in a number of vegetables.

Since F statistical value $>\mathrm{F}$ critical value and $\mathrm{P}<$ 0.05 , hence there were significant differences in the mean 
Table 13. Regression statistics on the bioavailability of Cd for DHS, RHS, and CHS in the gastric phase.

\begin{tabular}{|c|c|c|c|c|c|}
\hline Element & P-value & Slope & Equation & $\mathrm{R}^{2 \mathrm{a}}$ & $95 \% \mathrm{CI}^{\mathrm{b}}$ \\
\hline DHS & 0.00 & 23.60 & $\mathrm{y}=23.60 \mathrm{x}+4.34$ & 0.82 & {$[13.74,33.46]$} \\
\hline RHS & 0.22 & 11.11 & $\mathrm{y}=11.11 \mathrm{x}+6.07$ & 0.21 & {$[-8.19,30.40]$} \\
\hline CHS & 0.00 & 22.76 & $\mathrm{y}=22.76 \mathrm{x}+3.29$ & 0.94 & {$[17.40,28.12]$} \\
\hline a: coefficient of determination & b: confidence interval \\
\hline
\end{tabular}

Table 14. Regression statistics on the bioavailability of Cd for DHS, RHS, and CHS in the intestinal phase.

\begin{tabular}{|c|c|c|c|c|c|}
\hline Element & P-value & Slope & Equation & $\mathrm{R}^{2 \mathrm{a}}$ & $95 \% \mathrm{CI}^{\mathrm{b}}$ \\
\hline DHS & 0.00 & 16.98 & $\mathrm{y}=16.98 \mathrm{x}+3.69$ & 0.74 & {$[7.99,25.98]$} \\
\hline RHS & 0.08 & 10.11 & $\mathrm{y}=10.11 \mathrm{x}+4.06$ & 0.37 & {$[-1.71,21.93]$} \\
\hline CHS & 0.08 & 9.23 & $\mathrm{y}=9.23 \mathrm{x}+3.61$ & 0.37 & {$[-1.59,20.05]$} \\
\hline \multicolumn{2}{|l}{ a: coefficient of determination } & b: confidence interval \\
\hline
\end{tabular}

Cd bioaccessibilities observed at different treatment concentrations for DHS, RHS, and CHS in the gastric as well as in intestinal digestion. It was then followed by the Tukey-Kramer procedure and it was found that there were statistically significant differences between all three comparisons for DHS, RHS, and CHS in the gastric digestion. In the intestinal digestion, it was found that there were statistically significant differences between all three comparisons for RHS. As for DHS and CHS, there were statistically significant differences between all pairs of comparison except for T1 and T2.

The variation in metal bioavailabilities between the gastric and the intestinal extraction may be due to the chemical form of the metals, metal species, gastrointestinal tract contents, diet, nutritional status, microfibers of crystalline cellulose and phytates, phytochelatins, and vegetable species [110]. Furthermore, the metal bioaccessibilities may be affected by simulated parameters

Table 15. Daily intake of metals from the consumption of metalcontaminated WWS (mean \pm SE, $n=3$ ).

\begin{tabular}{|c|c|c|}
\hline \multirow{2}{*}{ Type of treatment } & \multicolumn{2}{|c|}{ Daily intake of metals $(\mathrm{mg} / \mathrm{d})$} \\
\hline & RHS & CHS \\
\hline \multicolumn{3}{|c|}{$\mathrm{Mn}$} \\
\hline $\mathrm{C}$ & $0.0004 \pm 0.0000$ & $0.0020 \pm 0.0001$ \\
\hline $\mathrm{T} 1$ & $0.0018 \pm 0.0001$ & $0.0157 \pm 0.0006$ \\
\hline $\mathrm{T} 2$ & $0.0017 \pm 0.0001$ & $0.0105 \pm 0.0008$ \\
\hline \multicolumn{3}{|c|}{$\mathrm{Cd}$} \\
\hline $\mathrm{C}$ & NIL*** & NIL $* * *$ \\
\hline $\mathrm{T} 1$ & $0.0190 \pm 0.0005$ & $0.0026 \pm 0.0001$ \\
\hline $\mathrm{T} 2$ & $0.0202 \pm 0.0007$ & $0.0059 \pm 0.0001$ \\
\hline
\end{tabular}

such as gastric and small intestinal $\mathrm{pH}$ and chemistry, gastric mixing, and gastric emptying rates[111].

\section{Daily Intake of $\mathrm{Mn}$ and $\mathrm{Cd}$}

The upper tolerable daily dietary intake limit (UL) were $11.000 \mathrm{mg} / \mathrm{d} /$ person for $\mathrm{Mn} \mathrm{[112]} \mathrm{and} 0.064 \mathrm{mg} / \mathrm{d} /$ person for Cd [113]. From the Table 15, it is observed that the DIM values obtained from raw and cooked WWS were all below the UL limits for $\mathrm{Mn}$ and $\mathrm{Cd}$. The mean DIM values ranged 0.0004 to $0.0157 \mathrm{mg} / \mathrm{d}$ for $\mathrm{Mn}$ and 0.0000 to $0.0202 \mathrm{mg} / \mathrm{d}$ for $\mathrm{Cd}$. However, the edible parley (Petroselinum crispum (Mill.) Nyman ex A.W. Hill) roots located near the old mining area in Romania were contaminated with high Mn and the DIM value was $11.35 \mathrm{mg} / \mathrm{d}$ which was slightly higher than the UL limit [80]. It was also found that the DIM values for $\mathrm{Cd}$ in green peppers, Capsicum annuum L. (0.09 mg/d) and tomatoes,

Table 16. HRI for Mn and Cd in raw and cooked WWS (mean $\pm \mathrm{SE}, \mathrm{n}=3$ ).

\begin{tabular}{|c|c|c|}
\hline \multirow{2}{*}{$\begin{array}{c}\text { Type of } \\
\text { treatment }\end{array}$} & \multicolumn{2}{|c|}{ Health risk index } \\
\cline { 2 - 3 } & \multicolumn{3}{|c|}{ RHS } & CHS \\
\hline \multicolumn{3}{|c|}{$\mathrm{Mn}$} \\
\hline $\mathrm{C}$ & $0.0264 \pm 0.0022$ & $0.1451 \pm 0.0065$ \\
\hline $\mathrm{T} 1$ & $0.1256 \pm 0.0061$ & $1.1187 \pm 0.0413$ \\
\hline $\mathrm{T} 2$ & $0.1213 \pm 0.0090$ & $0.7513 \pm 0.0576$ \\
\hline \multicolumn{2}{|c|}{$\mathrm{Cd}$} \\
\hline $\mathrm{C}$ & $\mathrm{NIL} * * *$ & $\mathrm{NIL} * * *$ \\
\hline $\mathrm{T} 1$ & $2.6348 \pm 0.0921$ & $18.9954 \pm 0.5291$ \\
\hline $\mathrm{T} 2$ & $5.8507 \pm 0.1252$ & $20.1777 \pm 0.7339$ \\
\hline
\end{tabular}


Solanum lycopersicum L. (0.07 mg/d) harvested from the wastewater irrigated farm in Botswana were higher than the UL limit [114]. the estimated DIM value for $\mathrm{Cd}$ in the vegetables like spinach (Beta vulgaris L.), amaranthus (Amaranthus caudatus L.) [46], etc. from agricultural lands in Bangladesh was $0.178 \mathrm{mg} / \mathrm{d}$ which was more than double the UL limit; they also found the DIM value for chromium $(\mathrm{Cr})(0.286 \mathrm{mg} / \mathrm{d})$ in the vegetables was higher than $0.200 \mathrm{mg} / \mathrm{d}$ set by the World Health Organization/ Food and Agriculture Organization (WHO/FAO, 2007) [115].

\section{Health Risk Index from Mn and Cd}

The HRI value by the consumption of raw and cooked WWS estimated for adults (average of 44 years old) in Selangor state, Malaysia is presented in Table 16. An HRI value of $>1$ showed there was a health risk involved if locals consumed Mn-contaminated cooked WWS (CHS) at $\mathrm{T} 1$. The health risks to be most concerned if the locals consumed Cd-contaminated raw and cooked WWS (RHS and CHS) at T1 and T2 due to the HRI values $>1$. The HRI value was highest (20.178) in CHS. In addition to WWS, spinach (Spinacia oleracea L.) irrigated with wastewater had HRI values $>1$ for Mn and Cd [116]. Furthermore, the vegetable such as coriander (Coriandrum sativum L.) harvested from wastewater and sewage water irrigated sites in Pakistan had high $\mathrm{Mn}$ and Cd with an HRI value of 0.92 [117] and 3.27 [118], respectively. Nevertheless, a slightly higher HRI value (3.40) for Cd was reported in the pepper (Capsicum frutescens L.) harvested from the greenhouse in Iran [119]. Apart from the $\mathrm{Mn}$ and $\mathrm{Cd}$, other elements such as arsenic (As), lead ( $\mathrm{Pb})$, molybdenum (Mo), copper $(\mathrm{Cu})$, nickel $(\mathrm{Ni})$, and selenium $(\mathrm{Se})$ were observed to be high in the mustard (Brassica campestris L.) harvested from wastewater irrigated site in Pakistan with HRI value of $69.86,10.95,5.516,2.732,2.447$, and 1.033 , respectively [120].

\section{Conclusions}

It was found that $\mathrm{Mn}$ and $\mathrm{Cd}$ bioavailability was higher for absorption in the gastric than the intestinal phase. In addition, the bioaccessibilities decreased in the order RHS $>$ CHS $>$ DHS for Mn, and as for Cd, it followed the order CHS $>$ DHS $>$ RHS. Regression analysis showed that both the $\mathrm{Mn}$ and $\mathrm{Cd}$ bioavailability was dependent on the type of samples (dried, raw, and cooked) and the treatment concentrations $(\mathrm{C}, \mathrm{T} 1$, and $\mathrm{T} 2)$. The estimated HRI values revealed that the WWS contaminated with $\mathrm{Mn}$ at different concentrations were free of any risks from consumption except for the Mn-contaminated cooked WWS at T1 whereas when consuming the raw and cooked Cd-contaminated WWS, it posed a higher risk toward health at all tested concentrations.

\section{Acknowledgements}

The financial support is given by Universiti Putra Malaysia (UPM) and the Ministry of Higher Education Malaysia through MyBrain15 (MyPhD) to this research is greatly appreciated by all the authors involved.

\section{References}

1. KHAIRIAH J., HABIBAH J., AHMAD MAHIR R., MAIMON A., AMINAH A., ISMAIL B.S. Studies on heavy metal deposits in soils from selected agricultural areas of Malaysia. Adv. Environ. Biol. 3, 3, 2009.

2. GILL M. Heavy metal stress in plants: A review. Int. J. Adv. Res. 2, 6, 2014.

3. SHA Z., YUE Y., CAO L. Measuring and analysis of nonessential element variation in soybean. In: Proceedings of the Seventh International Conference on Measuring Technology and Mechatronics Automation; 13-14 Jun 2015; IEEE: Nanchang, China, pp. 621-625, 2015. Accessed in 7 Mar 2017. Available at; http://ieeexplore.ieee.org/ document $/ 7263650 /$

4. CHOPRAAK., PATHAK C., PRASAD G. Scenario of heavy metal contamination in agricultural soil and its management. J. Appl. Nat. Sci. 1, 1, 2009.

5. HARIPRASAD N.V., DAYANANDA H.S. Environmental impact due to agricultural runoff containing heavy metals-a review. Int. J. Sci. Res. Publ. 3, 5, 2013.

6. SCHIPPER P.N.M., BONTEN L.T.C., PLETTE A.C.C., MOOLENAAR S.W. Measures to diminish leaching of heavy metals to surface waters from agricultural soils. Desalination 226, 1, 2008.

7. SUHAG A., GUPTA R., TIWARI A. Biosorptive removal of heavy metals from wastewater using duckweed. Inter. J. Biomed. Adv. Res. 2, 8, 2011.

8. CRUZ-GARCIA G.S., PRICE L.L. Ethnobotanical investigation of 'wild' food plants used by rice farmers in Kalasin, Northeast Thailand. J. Ethnobiol. Ethnomed. 7, 1, 2011.

9. HERNIWANTI, PRIATMADI J.B., YANUWIADI B., SOEMARNO. Water plants characteristic for phytoremediation of acid mine drainage passive treatment. Inter. J. Basic Appl. Sci. 13, 6, 2013.

10. KUMAR V., CHOPRA A.K. Reduction of pollution load of paper mill effluent by phytoremediation technique using water caltrop (Trapa natans L.). Cogent Environ. Sci. 2, 1, 2016.

11. MISHRA V. Accumulation of cadmium and copper from aqueous solutions using Indian lotus (Nelumbo nucifera). AMBIO: J. Hum. Environ. 38, 2, 2009.

12. ROBINSON B., DUWIG C., BOLAN N., KANNATHASAN M., SARAVANAN A. Uptake of arsenic by New Zealand watercress (Lepidium sativum). Sci. Total Environ. 301, 1, 2003.

13. UMAR M.A., WUNZANI D.K. Heavy metals in wild rice from Gure, Kagoro and Kaduna, Kaduna State, Nigeria. Inter. J. Sci. Technol. Res. 2, 5, 2013.

14. HUE N.V., MAI Y. Manganese toxicity in watermelon as affected by lime and compost amended to a Hawaiian acid Oxisol. HortScience 37, 4, 2002. 
15. BASILE A, SORBO S, CONTE B, COBIANCHI R.C., TRINCHELLA F., CAPASSO C., CARGINALE V. Toxicity, accumulation, and removal of heavy metals by three aquatic macrophytes. Inter. J. Phytoremediation 14, 4, 2012.

16. BHOWMIK S., DATTA B.K., SAHA A.K. Determination of mineral content and heavy metal content of some traditionally important aquatic plants of Tripura, India using atomic absorption spectroscopy. J. Agri. Technol. 8, 4, 2012.

17. LEUNG H.M., DUZGOREN-AYDIN N.S., AU C.K., KRUPANIDHI S., FUNG K.Y., CHEUNG K.C., WONG Y.K., PENG X.L., YE Z.H., YUNG K.K.L., TSUI M.T.K. Monitoring and assessment of heavy metal contamination in a constructed wetland in Shaoguan (Guangdong Province, China): Bioaccumulation of $\mathrm{Pb}, \mathrm{Zn}, \mathrm{Cu}$ and $\mathrm{Cd}$ in aquatic and terrestrial components. Environ. Sci. Pollut. Res. Int. 24, 10, 2017.

18. AUSTIN D.F. Water spinach (Ipomoea aquatica, Convolvulaceae): A food gone wild. Ethnobot. Res. Appl. 5, 2007.

19. GÖTHBERG A., GREGER M., BENGTSSON B.E. Accumulation of heavy metals in water spinach (Ipomoea aquatica) cultivated in the Bangkok region, Thailand. Environ. Toxicol. Chem. 21, 9, 2002.

20. EBERT A.W. Promotion of indigenous vegetables in Asia: Conservation and use of selected crops in Indonesia, the Philippines, and Taiwan. Acta Hort. 2011, 2011.

21. ONG H.C., CHUA S., MILOW P. Traditional knowledge of edible plants among the Temuan villagers in Kampung Jeram Kedah, Negeri Sembilan, Malaysia. Sci. Res. Essays 6, 4, 2011.

22. JU Y., ZHUO J., LIU B., LONG C. Eating from the wild: Diversity of wild edible plants used by Tibetans in Shangri-la region, Yunnan, China. J. Ethnobiol. Ethnomed. 9, 1, 2013.

23. 23. SHUMSKY S.A., HICKEY G.M., PELLETIER B., JOHNS T. Understanding the contribution of wild edible plants to rural social-ecological resilience in semi-arid Kenya. Ecol. Soc. 19, 4, 2014.

24. 24. ACHARYA K.P., ACHARYA R. Eating from the wild: Indigenous knowledge on wild edible plants in Parroha VDC of Rupandehi district, Central Nepal. Inter. J. Soc. For. 3, 1, 2010.

25. AZAM F.M.S., BISWAS A., MANNAN A., AFSANA N.A., JAHAN R., RAHMATULLAH M. Are famine food plants also ethnomedicinal plants? An ethnomedicinal appraisal of famine food plants of two districts of Bangladesh. Evid. Based Complement Alternat. Med. 2014, 2014.

26. KANG Y., ŁUCZAJ Ł., KANG J., ZHANG S. Wild food plants and wild edible fungi in two valleys of the Qinling Mountains (Shaanxi, central China). J. Ethnobiol. Ethnomed. 9, 1, 2013.

27. LAROCHELLE S., BERKES F. Traditional ecological knowledge and practice for edible wild plants: Biodiversity use by the Rarámuri, in the Sirerra Tarahumara, Mexico. Int. J. Sust. Dev. World Ecol. 10, 4, 2003.

28. SHUMSKY S., HICKEY G.M., JOHNS T., PELLETIER B., GALATY J. Institutional factors affecting wild edible plant (WEP) harvest and consumption in semi-arid Kenya. Land use policy 38, 2014.

29. UMAR K.J., HASSAN L.G., DANGOGGO S.M., LADAN M.J. Nutritional composition of water spinach (Ipomoea aquatica Forsk.) leaves. J. Appl. Sci. 7, 6, 2007.

30. ONG H.C., MOJIUN P.F.J., MILOW P. Traditional knowledge of edible plants among the Temuan villagers in Kampung Guntor, Negeri Sembilan, Malaysia. Afr. J. Agric. Res. 6, 8, 2011.
31. NUR SHAHIDAH M. Documentation and valuation of plant resources used by the Orang Asli at Kampung Lubuk Ulu Legong, Baling, Kedah. PhD [dissertation], Kuala Lumpur: University of Malaya, 2014. Accessed in 7 Mar 2017. Available at; http://studentsrepo.um.edu.my/4781/3/ Final_TEXT.pdf

32. LI W., LI Z. In situ nutrient removal from aquaculture wastewater by aquatic vegetable Ipomoea aquatica on floating beds. Water Sci. Technol. 59, 10, 2009.

33. RAI U.N., SINHA S. Distribution of metals in aquatic edible plants: Trapa natans (Roxb.) Makino and Ipomoea aquatica Forsk. Environ. Monit. Assess. 70, 3, 2001.

34. WHO. Guidelines for drinking-water quality, $4^{\text {th }}$ edition. World Health Organization (WHO), Geneva, Switzerland. 2011.

35. KUMAR J.N., SONI H., KUMAR R.N., BHATT I. Macrophytes in phytoremediation of heavy metal contaminated water and sediments in Pariyej Community Reserve, Gujarat, India. Turk. J. Fish. Aquat. Sci. 8, 2, 2008.

36. BAYSA M.C., ANUNCIO R.R.S., CHIOMBON M.L.G., CRUZ J.P.R.D., RAMELB J.R.O. Lead and cadmium contents in Ipomoea aquatica Forsk. grown in Laguna de Bay. Philipp. J. Sci. 135, 2, 2006.

37. GÖTHBERG A., GREGER M., HOLM K., BENGTSSON B.E. Influence of nutrient levels on uptake and effects of mercury, cadmium, and lead in water spinach. J. Environ. Qual. 33, 4, 2004.

38. KUMAR N., BAUDDH K., DWIVEDI N., BARMAN S.C., SINGH D.P. Accumulation of metals in selected macrophytes grown in mixture of drain water and tannery effluent and their phytoremediation potential. J. Environ. Biol. 33, 5, 2012.

39. PRUSTY B.A.K., AZEEZ P.A., JAGADEESH E.P. Alkali and transition metals in macrophytes of a wetland system. Bull. Environ. Contam. Toxicol. 78, 5, 2007.

40. FAO/WHO. Contaminants. In: Codex Alimentarius, vol. XVII, Edition 1. Codex Alimentarius Commision, Food and Agriculture Organization/World Health Organization (FAO/ WHO), Rome, Italy. 1984.

41. GHANI A., ALI Z., ISHTIAQ M., MAQBOOL M., PARVEEN S. Estimation of macro and micro nutrients in some important medicinal plants of Soon Valley, District Khushab, Pakistan. Afr. J. Biotechnol. 11, 78, 2012.

42. NIRMALI WICKRAMARATNE M., MADURANGA T.M., SANJAYA CHAMARA L.L. Contamination of heavy metals in aquatic vegetables collected from cultivation sites in Sri Lanka. J. Environ. Sci. Toxicol. Food Technol. 10, 11, 2016.

43. MARCUSSEN H., DALSGAARD A., HOLM P.E. Element concentrations in water spinach (Ipomoea aquatica Forssk.), fish and sediment from a wetland production system that receives wastewater from Phnom Penh, Cambodia. J. Environ. Sci. Heal. A 44, 1, 2009.

44. TANEE T., SUDMOON R., THAMSENANUPAP P., CHAVEERACH A. Effect of cadmium on DNA changes in Ipomoea aquatica Forssk. Pol. J. Environ. Stud. 25, 1, 2006.

45. GUAN B.T.H., MOHAMAT-YUSUFF F., HALIMOON N., YONG C.S.Y. Uptake of $\mathrm{Mn}$ and $\mathrm{Cd}$ by wild water spinach and their bioaccumulation and translocation factors. EnvironmentAsia 10, 1, 2017.

46. JOLLY Y.N., ISLAM A., AKBAR S. Transfer of metals from soil to vegetables and possible health risk assessment. SpringerPlus 2, 1, 2013.

47. LOTFY W.M., EZZ A.M., HASSAN A.A.M. Bioaccumulation of some heavy metals in the liver flukes 
Fasciola hepatica and F. gigantica. Iran. J. Parasitol. 8, 4, 2013.

48. TARALE P., CHAKRABARTI T., SIVANESAN S., NAOGHARE P., BAFANA A., KRISHNAMURTHI K. Potential role of epigenetic mechanism in manganese induced neurotoxicity. BioMed Res. Int. 2016, 2016.

49. SURI D.J., TANUMIHARDJO S.A. Effects of different processing methods on the micronutrient and phytochemical contents of maize: From A to Z. Compr. Rev. Food Sci. Food Saf. 15, 5, 2016.

50. BHATTACHARYYA M.H. Cadmium osteotoxicity in experimental animals: Mechanisms and relationship to human exposures. Toxicol. Appl. Pharm. 238, 3, 2009.

51. YANG L.S., ZHANG X.W., LI Y.H., LI H.R., WANG Y., WANG W.Y. Bioaccessibility and risk assessment of cadmium from uncooked rice using an in vitro digestion model. Biol. Trace Elem. Res. 145, 1, 2012.

52. FEKI-TOUNSI M., HAMZA-CHAFFAI A. Cadmium as a possible cause of bladder cancer: A review of accumulated evidence. Environ. Sci. Pollut. Res. 21, 18, 2014.

53. KOCH W., KARIM M.R., MARZEC Z., MIYATAKA H., HIMENO S., ASAKAWA Y. Dietary intake of metals by the young adult population of Eastern Poland: Results from a market basket study. J. Trace Elem. Med. Biol. 35, 2016.

54. OTHMAN C. Dietary intake of cadmium, copper, lead and zinc from the consumption of cereal foods in Dar es Salaam, Tanzania. Tanz. J. Nat. Appl. Sci. 2, 1, 2012.

55. SONG D., ZHUANG D., JIANG D., FU J., WANG Q. Integrated health risk assessment of heavy metals in Suxian County, South China. Int. J. Environ. Res. Public Health 12, 7, 2015.

56. GODT J., SCHEIDIG F., GROSSE-SIESTRUP C., ESCHE V., BRANDENBURG P., REICH A., GRONEBERG D.A. The toxicity of cadmium and resulting hazards for human health. J. Occup. Med. Toxicol. 1, 1, 2006.

57. ROTH J.A. Homeostatic and toxic mechanisms regulating manganese uptake, retention, and elimination. Biol. Res. 39, 1, 2006.

58. BERNARD A. Cadmium \& its adverse effects on human health. Indian J. Med. Res. 128, 4, 2008.

59. PEJOVIĆ-MILIĆ A., CHETTLE D.R., MCNEILL F.E. Quantification of manganese in human hand bones: A feasibility study. Phys. Med. Biol. 53, 15, 2008.

60. YUSWIR N.S., PRAVEENA S.M., ARIS A.Z., HASHIM Z. Bioavailability of heavy metals using in vitro digestion model: A state of present knowledge. Rev. Environ. Health 28, 4, 2013.

61. CUOMO V., LUCIANO F.B., MECA G., RITIENI A., MAÑES J. Bioaccessibility of glucoraphanin from broccoli using an in vitro gastrointestinal digestion model. CyTA-J. Food 13, 3, 2015.

62. VALLEJO F., GIL-IZQUIERDO A., PÉREZ-VICENTE A., GARCÍA-VIGUERA C. In vitro gastrointestinal digestion study of broccoli inflorescence phenolic compounds, glucosinolates, and vitamin C. J. Agric. Food Chem. 52, 1, 2004.

63. PODSĘDEK A., REDZYNIA M., KLEWICKA E., KOZIOŁKIEWICZ M. Matrix effects on the stability and antioxidant activity of red cabbage anthocyanins under simulated gastrointestinal digestion. BioMed Res. Inter. 2014, 2014.

64. RUTZKE C.J., GLAHN R.P., RUTZKE M.A., WELCH R.M., LANGHANS R.W., ALBRIGHT L.D., COMBS JR., GERALD F., WHEELER R.M. Bioavailability of iron from spinach using an in vitro/human Caco-2 cell bioassay model. Habitation 10, 1, 2004.
65. HU J., WU F., WU S., CAO Z., LIN X., WONG M.H. Bioaccessibility, dietary exposure and human risk assessment of heavy metals from market vegetables in Hong Kong revealed with an in vitro gastrointestinal model. Chemosphere 91, 4, 2013.

66. PAN X.D., WU P.G., JIANG X.G. Levels and potential health risk of heavy metals in marketed vegetables in Zhejiang, China. Sci. Rep. 6, 2016.

67. JENA V., DIXIT S., GUPTA S. Risk assessment of heavy metal toxicity through edible vegetables from industrial area of Chhattisgarh. Inter. J. Res. Environ. Sci. Technol. 2, 4, 2012.

68. MAHMOOD A., MALIK R.N. Human health risk assessment of heavy metals via consumption of contaminated vegetables collected from different irrigation sources in Lahore, Pakistan. Arabian J. Chem. 7, 1, 2014.

69. ORISAKWE O.E., NDUKA J.K., AMADI C.N., DIKE D.O., BEDE O. Heavy metals health risk assessment for population via consumption of food crops and fruits in Owerri, South Eastern, Nigeria. Chem. Cent. J. 6, 1, 2012.

70. WANG X., SATO T., XING B., TAO S. Health risks of heavy metals to the general public in Tianjin, China via consumption of vegetables and fish. Sci. Total Environ. 350, 1, 2005.

71. SINGH A., SHARMA R.K., AGRAWAL M., MARSHALL F.M. Risk assessment of heavy metal toxicity through contaminated vegetables from waste water irrigated area of Varanasi, India. Trop. Ecol. 51, 2, 2010.

72. HAGHIGHITALAB A., KARAMI M., SADEGHI E., SHAHI M. Investigation of heavy metals with some methods on vegetables. Int. J. Agri. Crop Sci. 7, 7, 2014.

73. SRIWICHAI W., COLLIN M., TRANBARGER T.J., BERGER J., AVALLONE S. Improvement of the content in bioaccessible lipophilic micronutrients in raw and processed drumstick leaves (Moringa oleifera Lam.). Food Sci. Technol. 75, 2017.

74. HUSSAIN A., ALAMZEB S., BEGUM S. Accumulation of heavy metals in edible parts of vegetables irrigated with waste water and their daily intake to adults and children, District Mardan, Pakistan. Food Chem. 136, 3, 2013.

75. ZHANG H., WANG Z.Y., YANG X., ZHAO H.T., ZHANG Y.C., DONG A.J., JING J., WANG J. Determination of free amino acids and 18 elements in freeze-dried strawberry and blueberry fruit using an Amino Acid Analyzer and ICP-MS with micro-wave digestion. Food Chem. 147, 2014.

76. NOWAK D., PIECHUCKA P., WITROWA-RAJCHERT D., WIKTOR A. Impact of material structure on the course of freezing and freeze-drying and on the properties of dried substance, as exemplified by celery. J. Food Eng. 180, 2016.

77. YAP C.K., ISMAILA., TAN S.G. Background concentrations of $\mathrm{Cd}, \mathrm{Cu}, \mathrm{Pb}$ and $\mathrm{Zn}$ in the green-lipped mussel Perna viridis (Linnaeus) from Peninsular Malaysia. Marine Poll. Bull. 46, 8, 2003.

78. AZIZ R., RAFIQ M.T., HE Z., LIU D., SUN K., XIAOE Y. In vitro assessment of cadmium bioavailability in Chinese cabbage grown on different soils and its toxic effects on human health. BioMed Res. Int. 2015, 2015.

79. MAT YUSOF A., MOHAMMAD M., ABDULLAHI M.A., MOHAMED Z., ZAKARIA R., ABDUL WAHAB R. Occurrence of intestinal parasitic contamination in selected consumed local raw vegetables and fruits in Kuantan, Pahang. Trop. Life Sci. Res. 28, 1, 2017.

80. HARMANESCU M., ALDA L.M., BORDEAN D.M., GOGOASA I., GERGEN I. Heavy metals health risk assessment for population via consumption of vegetables 
grown in old mining area; a case study: Banat County, Romania. Chem. Cent. J. 5, 1, 2011.

81. SANTOS E.E., LAURIA D.C., DA SILVEIRA C.P. Assessment of daily intake of trace elements due to consumption of foodstuffs by adult inhabitants of Rio de Janeiro city. Sci. Total Environ. 327, 1, 2004.

82. DSM. Selangor. Department of Statistics Malaysia (DSM), Putrajaya, Malaysia. 2015. Accessed in 2 Nov 2016. Available at; https://www.statistics.gov.my/index. $\mathrm{php} ? \mathrm{r}=$ column/cone\&menu_id=eGUyTm9RcEVZSIlmYW 45dmpnZHh4dz09

83. NURUL IZZAH A., AMINAH A., MD PAUZI A., LEE Y.H., WAN ROZITA W.M., SITI FATIMAH D. Patterns of fruits and vegetable consumption among adults of different ethnics in Selangor, Malaysia. Inter. Food Res. J. 19, 3, 2012.

84. KHAN S., FAROOQ R., SHAHBAZ S., KHAN M.A., SADIQUE M. Health risk assessment of heavy metals for population via consumption of vegetables. World Appl. Sci. J. 6, 12, 2009.

85. CHITSA H., MTAITA T., TABARIRA J. Nutrient content of water spinach (Ipomoea aquatica) under different harvesting stages and preservation methods in Zimbabwe. Inter. J. Biol. Chem. Sci. 8, 3, 2014.

86. DAN E.U., EBONG G.A. Impact of cooking utensils on trace metal levels of processed food items. Ann. Food Sci. Technol. 14, 2, 2013.

87. PELFRÊNE A., WATERLOT C., GUERIN A., PROIX N., RICHARD A., DOUAY F. Use of an in vitro digestion method to estimate human bioaccessibility of $\mathrm{Cd}$ in vegetables grown in smelter-impacted soils: The influence of cooking. Environ. Geochem. Health 37, 4, 2015.

88. RAHMAN M.M., ASADUZZAMAN M., NAIDU R. Consumption of arsenic and other elements from vegetables and drinking water from an arsenic-contaminated area of Bangladesh. J. Hazard. Mater. 262, 2013.

89. MORGAN J.N. Effects of processing on heavy metal content of foods. Adv. Exp. Med. Biol. 459, 1999.

90. NASERI M., RAHMANIKHAH Z., BEIYGLOO V., RANJBAR S. Effects of two cooking methods on the concentrations of some heavy metals (cadmium, lead, chromium, nickel and cobalt) in some rice brands available in Iranian Market. J. Chem. Health Risks 4, 2, 2014.

91. YUAN G.F., SUN B., YUAN J., WANG Q.M. Effects of different cooking methods on health-promoting compounds of broccoli. J. Zhejiang Univ. Sci. B 10, 8, 2009.

92. KAWASHIMA L.M., SOARES L.M.V. A fractionation study of mineral elements in raw and cooked leaf vegetables consumed in Southern Brazil. Alimentos e Nutrição Araraquara 14, 1, 2009.

93. OMAR N.A., PRAVEENA S.M., ARIS A.Z., HASHIM Z. Bioavailability of heavy metal in rice using in vitro digestion model. Inter. Food Res. J. 20, 6, 2013.

94. BABU M., DWIVEDI D.H., RAM Y.R., MEENA M.L. Bioaccumulation and distribution of heavy metals in water chestnut (Trapa natans var. bispinosa Roxb.) in the Lucknow Region. Afr. J. Agric. 8, 22, 2013.

95. BINDU T., SUMI M.M., RAMASAMY E.V. Decontamination of water polluted by heavy metals with taro (Colocasia esculenta) cultured in a hydroponic NFT system. The Environmentalist 30, 1, 2010.

96. SKORBIŁOWICZ E., SKORBIŁOWICZ M., MALINOWSKA D. Accumulation of heavy metals in organs of aqueous plants and its association with bottom sediments in Bug River (Poland). J. Ecol. Eng. 17, 4, 2016.

97. BRANKOVIĆ S., PAVLOVIĆ-MURATSPAHIĆ D., TOPUZOVIĆ M., GLIŠIĆ R., MILIVOJEVIĆ J., ĐEKIĆ
V. Metals concentration and accumulation in several aquatic macrophytes. Biotechnol. Biotechnol. Equip. 26, 1, 2012.

98. INTAWONGSE M., DEAN J.R. Uptake of heavy metals by vegetable plants grown on contaminated soil and their bioavailability in the human gastrointestinal tract. Food Addit. Contam. 23, 1, 2006.

99. ODUJEBE F., OYEYIOLA A.O., OLAYINKA K. Use of the physiologically based extraction test for the assessment of bioaccessibility of toxic metals in vegetables grown on contaminated soils. J. Health Pollut. 6, 10, 2016.

100. ETCHEVERRY P., GRUSAK M.A., FLEIGE L.E. Application of in vitro bioaccessibility and bioavailability methods for calcium, carotenoids, folate, iron, magnesium, polyphenols, zinc, and vitamins B6, B12, D, and E. Front. Physiol. 3, 2012.

101. ADAWR. Maximum levels of metal contaminants in food: Australia New Zealand Food Standards Code - Standard 1.4.1 - contaminants and natural toxicants, Table to Clause 2. Australian Department of Agriculture and Water Resources (ADAWR), Canberra, Australia. 2015. Accessed in 1 Nov 2016. Available at; https://www.legislation.gov. au/Details/F2011C00542

102. EC. Commission Regulation: Setting maximum levels for certain contaminants in foodstuffs, No. 1881/2006 of 19 December 2006. European Commission (EC), Brussels, Germany. 2006. Accessed in 31 Oct 2016. Available at; https://health.gov.mt/en/environmental/Documents/ Legislations/Pharmacologically/17regec1881_2006e.pdf

103. HKFEHD CFS. Hong Kong Food Adulteration (Metallic Contamination) Regulations 1997 (cap.132v). Second schedule: Maximum permitted concentration of certain metals in specified foods. Hong Kong Food and Environmental Hygiene Department, Centre for Food Safety (HKFEHD CFS), Kowloon, Hong Kong. 2006. Accessed in 31 Oct 2016. Available at; http://www. legislation.gov.hk/blis_pdf.nsf/4f0db701c6c25d4a482575 5c00352e35/05FECBCB00468409482575EE0042BB5B/ \$FILE/CAP $132 \mathrm{~V}$ e b5.pdf

104. MOH. Malaysian Food Regulations: Maximum permitted proportion ofmetal contaminantinspecified food, Regulation 38, fourteenth schedule, Table 1. Ministry of Health $(\mathrm{MOH})$, Putrajaya, Malaysia. 1985. Accessed in 30 Oct 2016. Available at; http://fsis2.moh.gov.my/UploadFosim/ FAR/ 040810095931 F 590 F OURTEENTH\%20 SCHEDULE.pdf

105. CHEN Y., WU P., SHAO Y., YING Y. Health risk assessment of heavy metals in vegetables grown around battery production area. Sci. Agric. 71, 2, 2014.

106. CMH. Maximum levels of contaminants in foods: GB27622005. Chinese Ministry of Health (CMH), Beijing, China. 2005.

107. FAO/WHO. Codex Alimentarius Commission Food Additives and Contaminants: ALINORM 01/12A. Food and Agriculture Organization/World Health Organization (FAO/WHO), Rome, Italy. 2001.

108. WHO/EU. WHO and EU drinking water quality guidelines for heavy metals and threshold values leading to crop damage. World Health Organization Regional Office for Europe (WHO/EU). Geneva, Switzerland, 1983.

109. ERDEMIR U.S., GUCER S. Fractionation analysis and bioavailability of manganese in spinach (Spinacia oleracea L.) leaves. Chem. Spec. Bioavailab. 25, 4, 2013.

110. FU J., CUI Y. In vitro digestion/Caco-2 cell model to estimate cadmium and lead bioaccessibility/bioavailability 
in two vegetables: The influence of cooking and additives. Food Chem. Toxicol. 59, 2013.

111. CUI Y., FU J., CHEN X. Speciation and bioaccessibility of lead and cadmium in soil treated with metal-enriched Indian mustard leaves. J. Environ. Sci. 23, 4, 2011.

112. FDA. Dietary reference intakes for vitamin A, vitamin K, arsenic, boron, chromium, copper, iodine, iron, manganese, molybdenum, nickel, silicon, vanadium, and zinc. Food and Drug Administration (FDA), National Academy Press: Washington, DC, United States. 2001.

113. GARCIA-RICO L., LEYVA-PEREZ J., JARA-MARINI M.E. Content and daily intake of copper, zinc, lead, cadmium, and mercury from dietary supplements in Mexico. Food Chem. Toxicol. 45, 9, 2007.

114. LIKUKU A.S., OBUSENG G. Health risk assessment of heavy metals via dietary intake of vegetables irrigated with treated wastewater around Gaborone, Botswana. In: Proceedings of the International Conference on Plant, Marine and Environmental Sciences; 1-2 Jan 2015; IICBEE: Kuala Lumpur, Malaysia, pp. 32-37, 2015. Accessed in 7 Mar 2017. Available at; http://iicbe.org/ upload/3022C0115069.pdf

115. WHO/FAO. Joint WHO/FAO food standards program code Alimentarius Commission 13th session, report of the thirty eight session of the codex committee on food hygiene. World Health Organization/Food and Agriculture Organization (WHO/FAO). Texas, USA, 2007.
116. BALKHAIR K.S., ASHRAF M.A. Field accumulation risks of heavy metals in soil and vegetable crop irrigated with sewage water in western region of Saudi Arabia. Saudi J. Biol. Sci. 23, 1, 2016.

117. JAN F.A., ISHAQ M., KHAN S., IHSANULLAH I., AHMAD I., SHAKIRULLAH M. A comparative study of human health risks via consumption of food crops grown on wastewater irrigated soil (Peshawar) and relatively clean water irrigated soil (lower Dir). J. Hazard. Mater. 179, 1, 2010.

118. IQBAL H.H., TASEER R., ANWAR S., MUMTAZ M., SHAHID N. Human health risk assessment: Heavy metal contamination of vegetables in Bahawalpur, Pakistan. Bull. Environ. Stud. 1, 1, 2016.

119. SOHRABI M., BEIGMOHAMMADI Z., CHERAGHI M., MAJIDIFAR S., JAHANGARD A. Health risks of heavy metals for population via consumption of greenhouse vegetables in Hamadan, Iran. Arch. Hyg. Sci. 4, 4, 2015.

120. KHAN Z.I., AHMAD K., ASHRAF M., YASMEEN S., ASHFAQ A., SHER M. Metal accumulation in a potential winter vegetable mustard (Brassica campestris L.) irrigated with different types of waters in Punjab, Pakistan. Pak. J. Bot. 48, 2, 2016. 